Bangladesh J. Bot. 48(2): 265-270, 2019 (June)

\title{
ANTIOXIDANT POTEINTIAL AND ACTIVITY OF AERIAL PARTS OF EIGHT MEDICINAL PLANTS OF UTTARAKHAND, INDIA
}

\author{
Shakuli Kashyap, PB Rao ${ }^{1}$, P Mishra* ${ }^{2}$ and Supriya ${ }^{3}$ \\ Department of Biological Sciences, College of Basic Sciences \& Humanities, \\ Uttarakhand, India
}

Keywords: Medicinal plants, Antioxidants potential, Peroxidase

\begin{abstract}
The antioxidant potential of aerial parts of eight medicinal plant species were investigated by 1,1diphenyl-2-picrylhydrazyl (DPPH) radical scavenging, Ferrous ion-chelating (FCA) and ferric reducing antioxidant power assays in five different concentrations and the mean values ranged from 20.39 to $83.01 \%$, 17.21 to $48.62 \%$ and 11.70 to $21.65 \mu \mathrm{g}$ Trolox equivalent/mg extract, respectively. Total phenolic and flavonoid contents ranged from 4.83 to $10.46 \mu \mathrm{g}$, gallic acid equivalent/mg extract and 1.12 to $13.11 \mu \mathrm{g}$ quercitin equivalent/mg extract. Enzymatic antioxidants (Unit/mg fresh weight): superoxide dismutase, catalase and peroxidase values ranged from 14.86 to $49.81,60.00$ to 141.33 and 0.25 to 0.60 , respectively. Considering the overall assay M. Pudica can be considered as the potent candidate for displaying antioxidant activity among the experimental plants.
\end{abstract}

\section{Introduction}

The oxidative stress is an imbalance between oxidants and antioxidants in favor of the oxidants potentially leading to damage. Over production of various activated oxygen species are considered to be the main contributor to oxidative stress (Ellnain-Wojtaszek et al. 2003). Natural antioxidants obtained from vegetables, fruits and medicinal plants induce the protective action which has been attributed to the presence of polyphenolic compounds and antioxidant vitamins including ascorbic acid, tocopherol, $\beta$-carotene, flavonoids, tannins, anthocyanins and other phenolic constituents (Soong and Barlow 2004). In India, many plant species have been investigated for their beneficial source of antioxidants (Surveswaran et al. 2007). A comparative, multi-method screening of antioxidant activity of Indian medicinal plant species is needed to select new sources of safe and inexpensive natural antioxidants. The objectives of the present study are to examine the total antioxidant capacity (DPPH, FCA, and FRAP), determining non-enzymatic antioxidants (total phenolic and flavonoid contents) and explore enzymatic antioxidants (SOD, CAT and POD) in aerial parts of eight different medicinal plants.

\section{Materials and Methods}

Aerial parts of plants were collected from MRDC, Pantnagar, India (Table 1) and brought to the laboratory, washed, shade dried, powdered and stored at laboratory conditions. The extracts were prepared by taking $10 \mathrm{~g}$ of dried powdered material in $100 \mathrm{ml}$ of aqua-methanol (70\%) and kept for ten days. The supernatant was collected by filtration and solvent was evaporated in a water bath and used for further experimentation.

2, 2- diphenyl -1- picrylhydrazyl (DPPH) radical scavenging assay was carried out by using the procedure described by Brand-Williams et al. (1995) with modifications and calculated by the formula: DPPH radical scavenging activity $(\%)=\left[1-\left(A_{t} / A_{o}\right)\right] \times 100$ where $A_{t}$ is absorbance

\footnotetext{
*Author for correspondence: <pradeepjnkvv@gmail.com>. ${ }^{1}$ Department of Biological Sciences, GBPUAT, Pantnagar, 263145, India. ${ }^{2}$ College of Agriculture, Powarkheda, JNKVV, (MP), India. ${ }^{3}$ Faculty of Agricultural Sciences, SGT University, Gurgaon, Haryana 122006, India
} 
(517 nm) of the sample and $\mathrm{A}_{\mathrm{o}}$ of control. The $\mathrm{IC}_{50}$ was also calculated and compared with gallic acid and Trolox standard. Ferrous ion-chelating assay (FCA) assay was performed according to Hsu et al. (2003). The metal ion chelating activity $\left(\mathrm{Fe}^{2+}\right)$ was calculated as: FCA $(\%)=\left[1-\left(\mathrm{A}_{\mathrm{t}} /\right.\right.$ $\left.\left.A_{o}\right)\right] \times 100$ where $A_{t}$ is the absorbance $(562 \mathrm{~nm})$ of sample and $A_{o}$ of control. The $\mathrm{IC}_{50}$ value was also calculated and compared with $\mathrm{Na}_{2}$ EDTA standard. Ferric reducing antioxidant power (FRAP) assay was determined by the procedure of Benzie and Strain (1996).

Table 1. Antioxidant profiling and activity in aerial parts of selected medicinal plant species.

\begin{tabular}{|c|c|c|}
\hline $\begin{array}{l}\text { Family/ } \\
\text { species }\end{array}$ & $\begin{array}{l}\text { Vernacular } \\
\text { names }\end{array}$ & $\begin{array}{l}\text { Medicinal } \\
\text { uses }\end{array}$ \\
\hline $\begin{array}{l}\text { Acanthaceae: } \\
\text { Andrographis paniculata } \\
\text { (Burm.f.) Nees }\end{array}$ & $\begin{array}{l}\text { H: Kalmegh } \\
\text { E: King of } \\
\text { bitters }\end{array}$ & $\begin{array}{l}\text { Antipyretic, anti-inflammatory, expectorant, depurative, } \\
\text { anthelmintic, antifungal, antityphoid, hepatoprotective, } \\
\text { antibacterial and antihypertensive agent. }\end{array}$ \\
\hline $\begin{array}{l}\text { Apiaceae } \\
\text { Centella asiatica (L.) Urb. }\end{array}$ & $\begin{array}{l}\text { H:Manduk } \\
\text { parni } \\
\text { E: Indian } \\
\text { pennywort }\end{array}$ & $\begin{array}{l}\text { Skin diseases (eczema, ulcers, etc.), brain stimulant, } \\
\text { controlling dysentery, wound healing agent and } \\
\text { antihypertensive agent. As a remedy against asthma, } \\
\text { anaemia and inflammations. }\end{array}$ \\
\hline $\begin{array}{l}\text { Asteraceae } \\
\text { Artimissia аппиа L. }\end{array}$ & $\begin{array}{l}\text { H: Malaria } \\
\text { booti }\end{array}$ & $\begin{array}{l}\text { Used against malaria, curing cough, cold, diarrhoea and } \\
\text { fever. Effective against cancer, leishmania, trypanosoma } \\
\text { and some viruses. }\end{array}$ \\
\hline $\begin{array}{l}\text { Asteraceae } \\
\text { Eclipta alba (L.) Hassk. }\end{array}$ & $\begin{array}{l}\text { H: Bhringaraj } \\
\text { E: Trailing } \\
\text { eclipta }\end{array}$ & $\begin{array}{l}\text { Anti-inflammatory, anthelmintic, carminative and } \\
\text { diuretic. Fresh juice of leaves for treating oedema, fever, } \\
\text { lever disorders and rheumatic joint pains; improve } \\
\text { appetite and to stimulate digestion. }\end{array}$ \\
\hline $\begin{array}{l}\text { Euphorbiaceae } \\
\text { Phyllanthus niruri L. }\end{array}$ & $\begin{array}{l}\text { H: Bhoomi } \\
\text { amla } \\
\text { E: Country } \\
\text { gooseberry }\end{array}$ & $\begin{array}{l}\text { Useful in ailments like dysentery, influenza, vaginitis, } \\
\text { diabetes, jaundice, kidney stone, dyspepsia. Plant is } \\
\text { antihepatotoxic, antihepatitis-B, antihyperglycemic, } \\
\text { antiviral, antibacterial and diuretic. }\end{array}$ \\
\hline $\begin{array}{l}\text { Mimosaceae } \\
\text { Mimosa púdica } \mathrm{L} .\end{array}$ & $\begin{array}{l}\text { H: Lajwanti } \\
\text { E: Touch me not }\end{array}$ & $\begin{array}{l}\text { Antiseptic, carminative, in burning sensation of } \\
\text { dysentery and morbid condition of vagina. }\end{array}$ \\
\hline $\begin{array}{l}\text { Scrophulariaceae } \\
\text { Bacopa monnieri (L.) } \\
\text { Wettst. }\end{array}$ & $\begin{array}{l}\text { H: Brahmi } \\
\text { E: Thyme } \\
\text { leaved gratiola }\end{array}$ & $\begin{array}{l}\text { Anticancerous, memory enhancer and tranquilliser. The } \\
\text { plant is anodyne, carminative, digestive, anti- } \\
\text { inflammatory, anticonvulsant, depurative, cardio-tonic } \\
\text { and bronchodialator. }\end{array}$ \\
\hline $\begin{array}{l}\text { Solanaceae } \\
\text { Solanum nigrum } \mathrm{L} .\end{array}$ & $\begin{array}{l}\text { H: Makoi } \\
\text { E: Black night } \\
\text { shade }\end{array}$ & $\begin{array}{l}\text { Useful in vitiated conditions of tridosha, rheumatalgia, } \\
\text { swellings, cough, asthma, bronchitis, wounds, ulcers, } \\
\text { flatulence, dyspepsia, strangury, hepatomegaly, otalgia } \\
\text { and hiccough (Paithankar et al. 2011, Srivastava et al. } \\
2012 \text { and Umadevi et al. 2013). }\end{array}$ \\
\hline
\end{tabular}

$\mathrm{H}=$ Hindi and $\mathrm{E}=$ English common name(s).

Total phenolic content was determined by procedure of Johnson and Schaal (1957) and expressed as gallic acid equivalent. Total flavonoid content was quantified by the method of Djeridane et al. (2006), with some modifications. Superoxide dismutase (SOD) activity was determined using the method used by Giannopolitis and Ries (1977). One unit of SOD activity was defined as the amount of enzyme which could cause 50\% inhibition of NBT photoreduction. 
Catalase (CAT) activity was determined by the titrimetric method described by Kato and Shimizu (1987). One unit of activity is expressed as $\mu$ moles of $\mathrm{H}_{2} \mathrm{O}_{2}$ consumed $/ \mathrm{min} / \mathrm{g}$ tissue. Peroxidase (POD) activity was determined using the method of Kar and Mishra (1976). One unit of peroxidase activity is expressed as one mole of pyrogallol oxidized $/ \mathrm{min} / \mathrm{g}$ tissue.

All the experiments were performed in triplicates and the results of five concentrations were expressed as mean. The data were subjected to two-way analysis of variance (ANOVA) using statistical software stpr 2 and differences were considered significant at CD 5\%.

\section{Results and Discussion}

In case of DPPH assay lowest activity (\%) was found in A. paniculata and highest activity was noticed in $M$. pudica at different concentrations (Table 2). The mean values $>50 \%$ were found in M. pudica followed by P. niruri, E. alba and B. monnieri. The potential of M. pudica was also supported by the $\mathrm{IC}_{50}$ values displaying the value $17 \mu \mathrm{g} / \mathrm{ml}$. It was followed by E. alba, P. niruri and B. monnieri indicating higher DPPH free radical scavenging activity (Fig. 1).

Table 2. Antioxidant activity (DPPH, FCA and FRAP) and total phenolic content (TPC) of aerial parts of different medicinal plants.

\begin{tabular}{|c|c|c|c|c|}
\hline Species & $\begin{array}{c}\text { DPPH } \\
(\%)\end{array}$ & $\begin{array}{c}\text { FCA } \\
(\%)\end{array}$ & $\begin{array}{c}\text { FRAP } \\
\mu \mathrm{g} \text { trolox equivalent } \\
(\mathrm{TE}) / \mathrm{mg} \text { extract }\end{array}$ & $\begin{array}{c}\text { TPC } \\
\mu \mathrm{g} \text { gallic acid equivalent } \\
(\mathrm{GAE}) / \mathrm{mg} \text { extract }\end{array}$ \\
\hline A. аппиа & $47.29^{\mathrm{H}}$ & $33.01^{\mathrm{C}}$ & $16.00^{\mathrm{C}}$ & $8.13^{\mathrm{C}}$ \\
\hline A. paniculata & $20.39^{\mathrm{J}}$ & $48.62^{\mathrm{A}}$ & $11.70^{\mathrm{D}}$ & $7.42^{\mathrm{D}}$ \\
\hline B. monnieri & $59.48^{\mathrm{F}}$ & $47.35^{\mathrm{A}}$ & $17.98^{\mathrm{B}}$ & $6.92^{\mathrm{E}}$ \\
\hline C. asiatica & $57.19^{\mathrm{G}}$ & $31.63^{\mathrm{D}}$ & $17.56^{\mathrm{B}}$ & $7.92^{\mathrm{C}}$ \\
\hline E. alba & $63.19^{\mathrm{E}}$ & $46.11^{\mathrm{A}}$ & $21.65^{\mathrm{A}}$ & $4.83^{\mathrm{F}}$ \\
\hline M. pudica & $83.01^{\mathrm{C}}$ & $17.21^{\mathrm{F}}$ & $19.58^{\mathrm{B}}$ & $8.76^{\mathrm{B}}$ \\
\hline P. niruri & $69.28^{\mathrm{D}}$ & $41.43^{\mathrm{B}}$ & $18.35^{\mathrm{B}}$ & $10.46^{\mathrm{A}}$ \\
\hline S. nigrum & $31.56^{\mathrm{I}}$ & $22.56^{\mathrm{E}}$ & $15.06^{\mathrm{C}}$ & $7.56^{\mathrm{C}}$ \\
\hline Gallic acid & $97.55^{\mathrm{B}}$ & NT & NT & NT \\
\hline Trolox & $98.58^{\mathrm{A}}$ & NT & NT & NT \\
\hline
\end{tabular}

Results are means values of five different concentrations, values of the same column, followed by the same letter (A - F) are not statistically different at CD at 5\%, as measured by two way ANNOVA using stpr 2.

NT - Not Tested.

The FCA (\%) exhibited a dose-response relationship as it increased with increasing concentration in each species (Table 2). Similar relation was also reported in $C$. sativum and $P$. crispum by Mirzaei and Khatami (2013). In the present study, lowest and highest FCA (\%) was noticed in M. pudica and A. paniculata respectively, which are in close agreement with results of Goncalves (2013). The $\mathrm{IC}_{50}$ value of FCA assay was found highest in S. nigrum and lowest in A. paniculata (a lower $\mathrm{IC}_{50}$ value corresponds to a higher chelating ability) (Fig. 2). FRAP assay values were expressed in terms of Trolox equivalent (TE). A dose-response relationship was found in FRAP activity (Table 2).

In TPC assay a dose-response relationship was found among different species (Table 2). The TPC value ( $\mu$ g gallic acid equivalent $/ \mathrm{mg}$ extract) was lowest in E. alba and highest in P. niruri. Among 
the species, the TPC values followed the order: P. niruri $>M$. Pudica $>A$. annua $>C$. asiatica $>$ S. nigrum $>$ A. paniculata $>$ B. monnieri and $>E$. alba. Total flavonoid content ( $\mu$ g quercitin equivalent/mg extract) was lowest in A. paniculata and highest in A. апnиа as presented in Fig. 3. In the present study, the TFC values in different species followed the order: A. аппиа $>$ M. pudica $>$ P. niruri $>$ E. alba $>$ B. monnieri $>$ S. nigrum $>$ C. asiatica and $>$ A. paniculata.

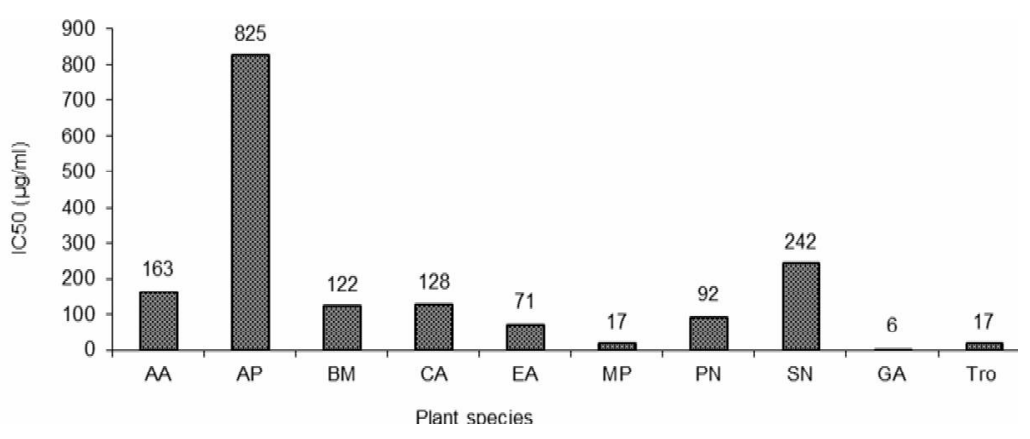

Fig. 1. DPPH free radical scavenging assay $\left(\mathrm{IC}_{50}\right)$.

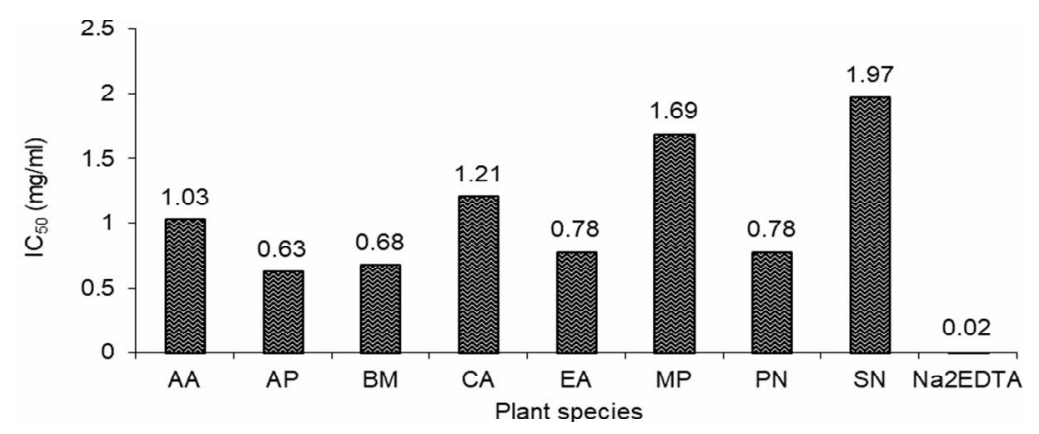

Fig. 2. Ferrous ion-chelating assay FCA $\left(\mathrm{IC}_{50}\right)$.

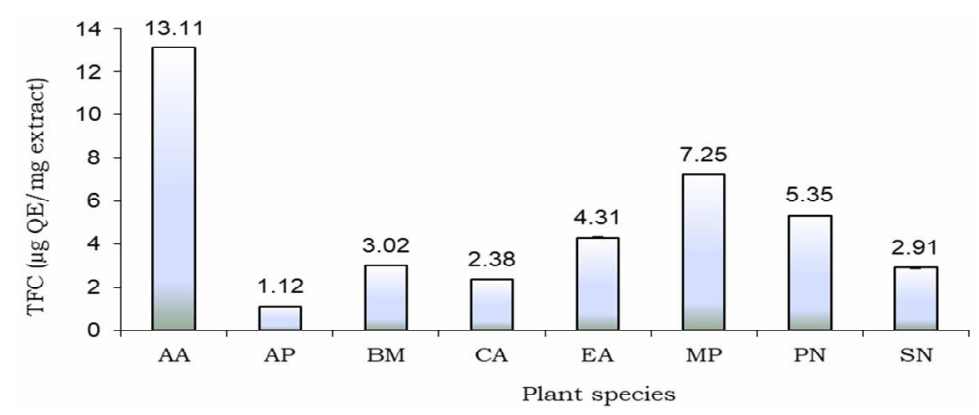

Fig. 3. Total flavonoid content ( $\mu \mathrm{g}$ QE/mg extract). * For Figs 1, 2, 3 (AA) A. annua; (AP) A. paniculata; (BM) B. monnieri; (CA) C. asiatica; (EA) E. alba; (MP) M. pudica; (PN) P. niruri; (SN) S. nigrum; (GA) gallic acid and (Tro) Trolox. 
The antioxidant enzymes (SOD, CAT and POD) activities are presented in Figs 4, 5 and 6, respectively. Superoxide dismutase activity (Unit/mg fresh weight) was maximum in $M$. pudica followed by $B$. monnieri and minimum in S. nigrum. Interestingly, the highest SOD activity of $M$. pudica was more than three times higher than the minimum in $S$. nigrum. Among different species, the highest activity (U/mg FW) of catalase was observed in B. monnieri and lowest in $M$. pudica and the former species was found to contain 2.83 times higher than the latter species. The peroxidase activity among the species was maximum in A. paniculata and it is 2.4 times higher than the minimum in C. asiatica. Higher SOD (49.8 units/mg protein) and CAT (180.3 $\left.\mu \mathrm{M} \mathrm{H}_{2} \mathrm{O}_{2}\right)$ activity were also reported in E. alsinoides by Gomathi et al. (2012). The present results of SOD and CAT were found to be higher than the values reported in whole aerial parts of T. pauciflora by Stralin et al. (2012).

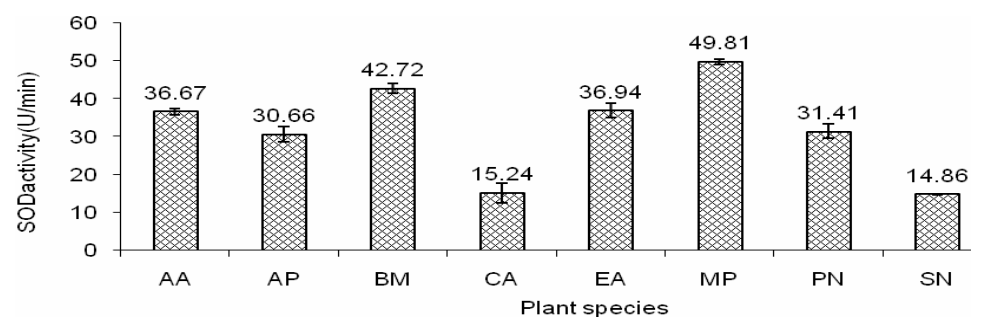

Fig. 4. Superoxide dismutase activity (SOD).

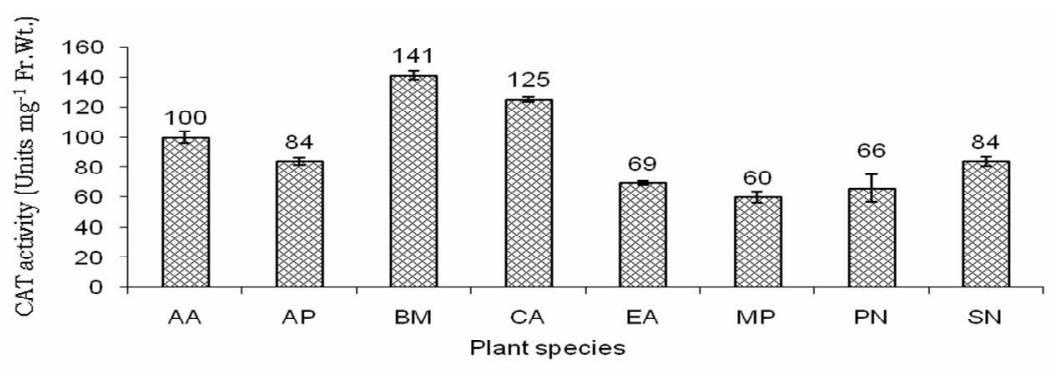

Fig. 5. Catalase activity (CAT)

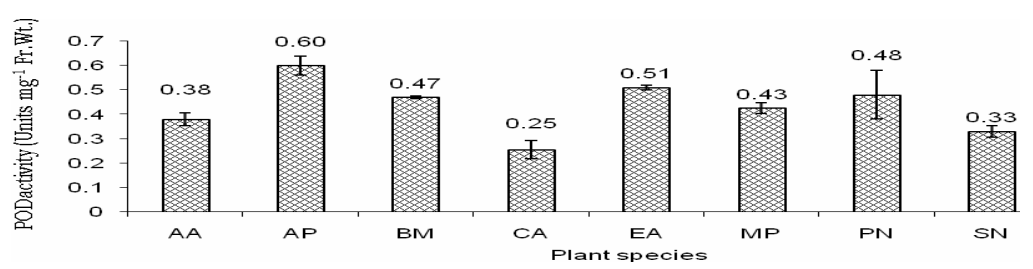

Fig. 6. Peroxidase activity (POD). * For Figs. 4, 5, 6 (AA) A. Аnпиа, (AP) A. Paniculata, (BM) B. monnieri; (CA) C. asiatica; (EA) E. alba; (MP) M. pudica; (PN) P. niruri; (SN) S. Nigrum.

Considering the overall assays of DPPH, FCA and FRAP M. pudica, E. alba, P. niruri and B. monnieri may be considered noticeably potent for displaying antioxidant activity. On the other hand, TPC and TFC assays indicated $P$. niruri, M. pudica and A. annua rich in polyphenol and flavonoid. Interestingly, $M$. pudica showed maximum SOD, minimum CAT and intermediate 
POD activities. However, A. paniculata displayed intermediate SOD and CAT and maximum POD activities. Considering all these, $M$. pudica can be considered relatively potent for displaying antioxidant activity. Further phytochemical investigations are required for isolating bioactive metabolites from it.

\section{Acknowledgements}

Authors are thankful to Dean, CBSH, Dean, PGS and DES, for their help. This study was supported by Dr. Ajeet Kumar, Incharge, MRDC, Pantnagar, India for allowing collection of plant materials.

\section{References}

Benzie IEF and Strain JJ 1996. Ferric reducing ability of plasma (FRAP) as a measure of antioxidant power: The FRAP Assay. Ann. Biochem. 239: 70-76.

Brand-Williams W, Cuvelier ME and Berset C 1995. Use of a free radical method to evaluate antioxidant activity. LWT Food Sci. Technol. 28(1): 25-30.

Djeridane A, Yousfi M, Nadjemi B, Boutassouna D, Stocker P and Vidal N 2006. Antioxidant activity of some Algerian medicinal plants extracts containing phenolic compounds. Food Chem. 97: 654-660.

Ellnain-Wojtaszek M, Kruczynski Z and Kasprzak J 2003. Investigation of the free radical scavenging activity of Ginkgo biloba L. leaves. Fitoterapia 74: 1-6.

Giannopolitis CN and Ries SK 1977. Superoxide dismutase: I. Occurrence in higher plants. Plant Physiol. 59: 309-314.

Gomathi D, Kalaiselvi M, Ravikumar G and Uma C 2012. Evaluation of enzymatic and non-enzymatic antioxidant potential of Evolvulus Alsinoides (L.). Asian J. Pharm. Clin. Res. 5(2): 159-163.

Goncalves S, Gomes D, Costa P and Romano A 2013. The phenolic content and antioxidant activity of infusions from Mediterranean medicinal plants. Ind. Crops Prod. 43: 465-471.

Hsu CL, Chen W, Weng YM and Tseng CY 2003. Chemical composition, physical properties, and antioxidant activities of yam flours as a $\square$ ected by di $\square$ erent drying methods. Food Chem. 83: 85-92.

Johnson G and Schaal LA 1957. Cholorogenic and ortho-dihydroxy phenols in scab resistant Russet Burbank and scab susceptible triumph potato tubers of different maturities. Phytopathology 47: 253-258.

Kar M and Mishra D 1976. Catalase, peroxidase and polyphenol oxidase activities during rice leaf senescence. Plant Physiol. 57: 315-319.

Kato M and Shimizu S 1987. Chlorophyll metabolism in higher plants. VII.Chlorophyll degradation in senescing tobacco leaves; phenolic-dependent peroxidative degradation. Can. J. Bot. 65: 729-735.

Mirzaei A and Khatami R 2013. Antioxidant and Iron Chelating Activity of Coriander sativum and Petroselinum crispum. Bull. Env. Pharmacol. Life Sci. 2(7): 27-31.

Paithankar VV, Raut KS, Charde RM and Vyas JV 2011. Review article: Phyllanthus niruri: A magic Herb. Res. Pharm. 1(4): 1-9.

Soong YY and Barlow PJ 2004. Antioxidant activity and phenolic content of selected fruit seeds. Food Chem. 88: 411-417.

Srivastava V, Sharma A and Alam I 2012. A review on ethnomedical and traditional uses of Mimosa pudica (Chui-Mui). Int. J. Pharm. 3(2): 41-44

Stralin T, Raj AC, Ragavendran P and Gopalakrishnan VK 2012. Phytochemical screening, functioning groups and element analyses of Tylophora pauciflora Wight and Arn. Int. Res. J. Pharm. 3(6): 180-183.

Surveswaran S, Cai YZ, Corke H and Sun M 2007. Systematic evaluation of natural phenolic antioxidants from 133 Indian medicinal plants. Food Chem. 102: 938-953.

Umadevi M, Sampath Kumar KP, Bhowmik D and Duraivel S 2013. Traditionally used anticancer herbs in India. J. Med. Plants Studies. 1(3): 56-74. 